\title{
High activity and low temperature optima of extracellular enzymes in Arctic sediments: implications for carbon cycling by heterotrophic microbial communities
}

\author{
C. Arnosti ${ }^{1, *}$, B. B. Jørgensen ${ }^{2}$ \\ ${ }^{1}$ Department of Marine Sciences, 12-7 Venable Hall CB 3300, University of North Carolina, Chapel Hill, \\ North Carolina 27599, USA \\ ${ }^{2}$ Department of Biogeochemistry, Max Planck Institute for Marine Microbiology, 28359 Bremen, Germany
}

\begin{abstract}
The rate of the initial step in microbial remineralization of organic carbon, extracellular enzymatic hydrolysis, was investigated as a function of temperature in permanently cold sediments from 2 fjords on the west coast of Svalbard (Arctic Ocean). We used 4 structurally distinct polysaccharides (chondroitin sulfate, fucoidan, xylan and pullulan) to determine the temperature-activity responses of hydrolysis of a related class of compounds. All 4 enzyme activities showed similarly low temperature optima in the range of 15 to $18^{\circ} \mathrm{C}$. These temperature optima are considerably lower than most previous reports of temperature optima for enzyme activities in marine sediments. At $0^{\circ} \mathrm{C}$, close to the in situ temperature, these enzyme activities achieved 13 to $38 \%$ of their rates at optimum temperatures. In one experiment, sulfate reduction rates were measured in parallel with extracellular enzymatic hydrolysis in order to determine the relative temperature responses of the initial and terminal steps in microbial remineralization of carbon. The temperature optimum of sulfate reduction, $21^{\circ} \mathrm{C}$, was considerably lower than previous reports of sulfate reduction in marine sediments, but is consistent with recent studies of psychrophilic sulfate reducers isolated from Svalbard sediments. A calculation of potential carbon flow into the microbial food chain demonstrated that the activity of just one type of polysaccharide-hydrolyzing enzyme could in theory supply 21 to $100 \%$ of the carbon consumed via sulfate reduction across the temperature range investigated here. These characteristics suggest that these extracellular enzymes are well adapted to permanently cold temperatures.
\end{abstract}

KEY WORDS: Extracellular enzymes · Temperature $\cdot$ Carbon remineralization $\cdot$ Arctic sediments Resale or republication not permitted without written consent of the publisher

\section{INTRODUCTION}

The degradation of organic carbon in marine sediments is dependent upon the activities of a diverse range of heterotrophic microbes - the microbial food chain - which act in concert to remineralize complex substrates to $\mathrm{CO}_{2}$. The activities of these microbes in permanently cold environments, in contrast to their counterparts in temperate environments, are apparently not inhibited by low temperatures (e.g. Thamdrup \& Fleischer 1998, Knoblauch et al. 1999). Microbial remineralization of organic carbon is initiated by

•Email: arnosti@email.unc.edu the activities of extracellular enzymes, which cleave substrates to sizes sufficiently small $\left(<600 \mathrm{Da}_{\text {; }}\right.$ Weiss et al. 1991) to be transported across microbial membranes. Since remineralization rates in permanently cold sediments are comparable to those in temperate environments (Vetter \& Deming 1994, Arnosti et al. 1998, Glud et al. 1998), the extracellular enzymes excreted by microbes in such sediments must also be sufficiently active to fuel the microbial food chain.

Despite their importance in initiating carbon remineralization, however, relatively little is known about the activities and structural specificities of 
microbial extracellular enzymes in marine environments or about the organisms that produce them. This lack of knowledge is in part a reflection of the fact that only a small fraction of extant microbes have been obtained in pure culture (Pace 1997). The extracellular enzymes which have been most thoroughly studied in general originate from thermophilic and hyperthermophilic organisms (see Adams 1993 for a review), although a few psychrophiles have also been studied in detail (e.g. Feller et al. 1994b, Gerday et al. 1997).

Although these studies have provided the basis of our current understanding of the relationships between enzyme structure and function at extreme temperatures, they leave open key questions about the workings of microbial communities and the types of enzymes actually functional in natural systems. In particular, enzymes active in natural systems may originate from a variety of sources and processes. A complex microbial community itself potentially includes a range of enzyme sources. Members of the community may produce structurally distinct enzymes which target the same substrate but have different activities and/or temperature sensitivities (e.g. Nguyen et al. 2001, Chhabra et al. 2002). Some enzymes are produced by microbes on a constitutive basis, but extracellular enzymes can also be induced and actively excreted in response to specific environmental cues. Enzymes that retain activity in the environment might additionally originate via processes incidental to extracellular hydrolysis, for example due to viral lysis or cell leaching. Furthermore, the 'lifetime' of enzymes in sediments is completely unknown. Measurements made in sediments might thus include the contributions of extracellular enzymes that were previously produced in response to environmental cues that are no longer present.

In order to investigate the activities and specificities of extracellular enzymes that initiate sedimentary carbon cycling, therefore, studies of natural samples and systems are required. Furthermore, in order to understand the means by which rapid rates of carbon cycling are maintained under permanently cold conditions, the rates of individual steps in the carbon remineralization pathway must be studied as functions of temperature. Temperature-activity curves derived from studies of specific processes in natural samples can provide an indication of the extent to which these steps are adapted to permanently cold conditions.

In this study, the activities and structural specificities of microbial extracellular enzymes were investigated in permanently cold Arctic sediments by incubating slurries of homogenized sediments in a temperature gradient block (TGB) spanning a $40^{\circ} \mathrm{C}$ temperature range. If enzymes active in marine sediments originate from a variety of processes or a range of organisms, then TGB measurements will integrate their combined activities. Processes such as enzyme excretion by bacteria and the potential of 'preserved' enzymes to contribute to hydrolysis are then also reflected in these measurements. In a previous study, we compared the temperature response of a single enzyme activity across a range of environments (Arnosti et al. 1998). In this investigation, we expand our investigation of temperature responses to a broader range of 4 enzyme activities, all falling into the category of polysaccharide hydrolases.

We focused particularly on the hydrolysis of polysaccharides because carbohydrates constitute a high percentage of particulate and dissolved organic carbon in marine systems (Cowie \& Hedges 1984, Benner et al. 1992). The polysaccharides whose hydrolysis was measured in this study are all marine-derived and/or the activities of enzymes able to hydrolyze these structures have been measured in marine organisms (see discussion in Arnosti 2000). These polysaccharides differ substantially in monomer composition and structure: chondroitin sulfate consists of repeating units of N-acetyl galactoseamine and glucuronic acid, and fucoidan is a sulfated fucose-containing polysaccharide. Xylan is a linear polymer of xylose, while pullulan is a polymer of maltotriose (glucose) units. In order to interpret the temperature responses of these enzyme activities within the context of sedimentary carbon cycling in permanently cold environments, sulfate reduction, the terminal step in organic carbon remineralization in anoxic sediments, was also measured in parallel with extracellular enzymatic hydrolysis in 1 TGB experiment.

Temperature-activity relationships are frequently characterized on the basis of the optimum temperature as well as the temperature range over which activity occurs. In accordance with our previous study (Arnosti et al. 1998), 'psychrophilic' will be used here to refer to activities with a minimum temperature $<0^{\circ} \mathrm{C}$, a temperature optimum $\leq 15^{\circ} \mathrm{C}$, and a maximum temperature $<20^{\circ} \mathrm{C}$. Activities with a minimum temperature $\leq 0^{\circ} \mathrm{C}$, an optimum temperature $\leq 25^{\circ} \mathrm{C}$, and maximum temperatures $\leq 35^{\circ} \mathrm{C}$ will be referred to as 'psychrotolerant', and activities with an optimum in the range of $\sim 25$ to $40^{\circ} \mathrm{C}$ and maxima at $\sim 35$ to $45^{\circ} \mathrm{C}$ will be referred to as 'mesophilic'.

\section{MATERIALS AND METHODS}

Sample collection. Samples were collected in 2 fjords on the west coast of Svalbard. Stn J (Smeerenburgfjord, $79^{\circ} 42.808^{\prime} \mathrm{N}, 011^{\circ} 05.200^{\prime} \mathrm{E}$, sediment temperature $-0.4^{\circ} \mathrm{C}$ ) was sampled in early July 1999, and Stn AB (Van Keulenfjord, $77^{\circ} 35.130^{\prime}$ N, 01505.701' E, sediment temperature $+0.2^{\circ} \mathrm{C}$ ) was sampled in late 
June 2000. Surface seawater was collected with a bucket, and sediments with a Haps-corer (K. O. Maskiner). From each of 3 to 4 Haps cores, the upper layers of the sediment were discarded, and the 3 to $7 \mathrm{~cm}$ layer was collected in a glass jar filled to the top without a headspace. Sulfate reduction is the major terminal remineralization process in the 3 to $7 \mathrm{~cm}$ layer, as shown by measurements made in intact subcores cores collected from additional Haps cores from the same stations (O. Larsen et al. unpubl. data).

Slurry preparation. Seawater was sparged with $\mathrm{N}_{2}$, and homogenized sediment was slurried 1:1 (by volume) under $\mathrm{N}_{2}$ with the degassed seawater; $10 \mathrm{ml}$ portions of the slurry were dispensed into vacutainer tubes under $\mathrm{N}_{2}$ flow, gassed again with $\mathrm{N}_{2}$, stoppered, and placed in a $185 \mathrm{~cm}$ long aluminum temperature gradient block (TGB) which had 4 sets of parallel holes drilled along its length, allowing several experiments to be conducted simultaneously. The block was cooled at one end and heated at the other to maintain a stable temperature range from $-3^{\circ} \mathrm{C}$ to $37^{\circ} \mathrm{C}$. The temperature gradient in the block was checked at regular intervals; it remained constant within $\pm 1^{\circ} \mathrm{C}$. For each substrate at $\mathrm{Stn} A B, 17$ sample tubes were distributed along the temperature range at temperature intervals of 1.5 to $3.0^{\circ} \mathrm{C}$. A replicate sample was also included at 15 or $18^{\circ} \mathrm{C}$. At Stn J, 18 sample tubes were distributed along the temperature range. Within the space limitations in the TGB (in which multiple experiments were incubating simultaneously) as well as the practical limitations of sample analysis (each chromatographic run required 85 min analytical time), we sampled as many temperature points along the gradient as possible. After $4 \mathrm{~h}$ preincubation to allow the tubes to achieve thermal equilibrium, each tube was briefly removed, substrate was added, the tubes were re-gassed with $\mathrm{N}_{2}$, mixed by shaking and inversion, and returned to the TGB for further incubation.

The slurries for sulfate reduction rate measurements were prepared in the same manner, except that a substrate mix of short-chain fatty acids ( $5 \mathrm{mM}$ each of formate, acetate, propionate, butyrate, and lactate) was added to the slurry immediately before distribution to the tubes in order to ensure reproducibility between tubes. (Note that the substrate mix was added after Stn J slurry had been dispensed for measurement of hydrolysis rates.) The tubes were preincubated in the TGB for $1 \mathrm{~h}$ before $0.1 \mathrm{ml}(100 \mathrm{kBq})$ carrier-free ${ }^{35} \mathrm{~S}$ $\mathrm{SO}_{4}{ }^{2-}$ was injected through the rubber stoppers. The tubes were shaken, and incubated for $2.1 \mathrm{~d}$ in the TGB. Incubations were stopped and sulfides fixed by adding the slurry to $20 \mathrm{ml}$ cold $20 \%$ ZnAc-solution and storing at $4{ }^{\circ} \mathrm{C}$.

Substrates and sampling. The potential hydrolysis rates of fluorescently labeled chondroitin sulfate, fuco- idan, xylan and pullulan were determined as functions of incubation temperature. The fluorescently labeled substrates were synthesized and characterized as described in Arnosti (1995). Substrate addition levels (to $10 \mathrm{ml}$ slurry tube) were $0.82 \mu \mathrm{mol}$ monomer-equivalent for chondroitin sulfate, $0.79 \mu \mathrm{mol}$ monomer-equivalent for fucoidan, $0.80 \mu \mathrm{mol}$ monomer-equivalent for xylan and $2.5 \mu \mathrm{mol}$ monomer-equivalent for pullulan. One substrate was added to each tube, and for each substrate, a series of 18 tubes was incubated as described in the previous subsection. For each substrate, 4 additional tubes were incubated from which samples were periodically removed with a syringe to determine the extent of hydrolysis across a broad temperature range. When these 4 tubes showed that hydrolysis was detectable across the temperature range, the main tube series was sampled by removing ca. $1.5 \mathrm{ml}$ of slurry from each tube and filtering the slurry through a surfactant-free cellulose acetate (SFCA) $0.2 \mu \mathrm{m}$ poresize disposable filter. The filtered liquid was stored frozen until analysis. For xylan and pullulan, activity was detectable in all 4 monitor vials after ca. $30 \mathrm{~h}$ incubation, so the entire temperature range was sampled at 31 and $36 \mathrm{~h}$, respectively. For chondroitin sulfate, in contrast, little activity was detected in the high-temperature monitor vial, so incubation in the TGB was continued after the first set of samples was collected at $36 \mathrm{~h}$, and a second sample set was collected at $60 \mathrm{~h}$. Fucoidan hydrolysis has been previously found to be slow in sediments (Arnosti 2000), so sample incubation times were accordingly longer, and the entire temperature range was sampled at $79 \mathrm{~h}$ and again at $125 \mathrm{~h}$. Thermal controls, consisting of substrate added to tubes containing milli-Q water, showed no sign of thermally-induced substrate degradation.

Measurement of sulfate reduction rates. Sulfate reduction rates were determined using a single-step acid Cr-II distillation method to volatilize and trap the total reduced sulfur species (Fossing \& Jørgensen 1989). The $\mathrm{H}_{2} \mathrm{~S}$ evolved was precipitated in $5 \%$ ZnAc. After distillation, the ZnS suspension was mixed with scintillation fluid (Ultima Gold XR, Packard) and the sulfide radioactivity was counted in a liquid scintillation counter. A subsample of the supernatant from the fixed sediment was taken for sulfate radioactivity determination. Sulfate reduction rates were calculated according to Jørgensen (1978).

Sample analysis and rate calculations. The extent of polysaccharide hydrolysis was determined by injecting the filtered slurry liquid onto a HPLC/GPC (gel permeation chromatography) system consisting of a Shimadzu LC-10AT pump, a Sephadex G-50 gel column $(20.5 \times 1 \mathrm{~cm})$ connected in series to a Sephadex G-75 gel column $(18.5 \times 1 \mathrm{~cm}$, including $1 \mathrm{~cm} \mathrm{G25} \mathrm{gel} \mathrm{at}$ the base), and a Hitachi L-7480 fluorescence detector 
(excitation $490 \mathrm{~nm}$, emission $530 \mathrm{~nm}$ ). The mobile phase was $100 \mathrm{mM} \mathrm{NaCl} / 50 \mathrm{mM} \mathrm{Na}_{2} \mathrm{HPO}_{4} / \mathrm{NaH}_{2} \mathrm{PO}_{4}$ buffer, pH 8.0, at a flow rate of $1.0 \mathrm{ml} \mathrm{min}^{-1}$. The column set was calibrated with a series of FITC-dextran standards (150, 10 and $4 \mathrm{kD}$ ) and fluroscein isothiocyanate-glucose plus fluoresceinamine in order to determine the elution times corresponding to these different molecular weight classes. Hydrolysis rates were calculated as described in Arnosti (1995, 2000). In brief, hydrolysis of a polysaccharide leads to a decrease in molecular weight that can be detected by changes in elution time, as seen for chondroitin sulfate incubated at $18^{\circ} \mathrm{C}$ (Fig. 1). By quantifying the proportion of the fluorescence signal eluting in each molecular weight class at a given time, one can calculate the minimum number of times a polysaccharide of known initial molecular weight must be hydrolyzed in order to reduce it to the observed distribution. For chondroitin sulfate (Fig. 1), for example, $75 \%$ of the substrate eluted in the $>50 \mathrm{kD}$ size class at $0 \mathrm{~h}$, decreasing to $14 \%$ at $36 \mathrm{~h}$ and finally to $0.6 \%$ at $60 \mathrm{~h}$. The fraction of substrate nominally eluting in the glucose size-class simultaneously changed from 2.2 to 22 to $43 \%$ at 0,36 , and $60 \mathrm{~h}$, respectively. (Note that limitations on the resolution which can be achieved with gel permeation chromatography columns lead to some of the initial substrate being assigned to lower molecular weight classes; this factor can contribute to an underestimate of the hydrolysis rate, as discussed in Arnosti 1995.) Note also that the rates reported here are potential hydrolysis rates (as discussed in Arnosti 1995), since the fluorescently labeled polysaccharides compete

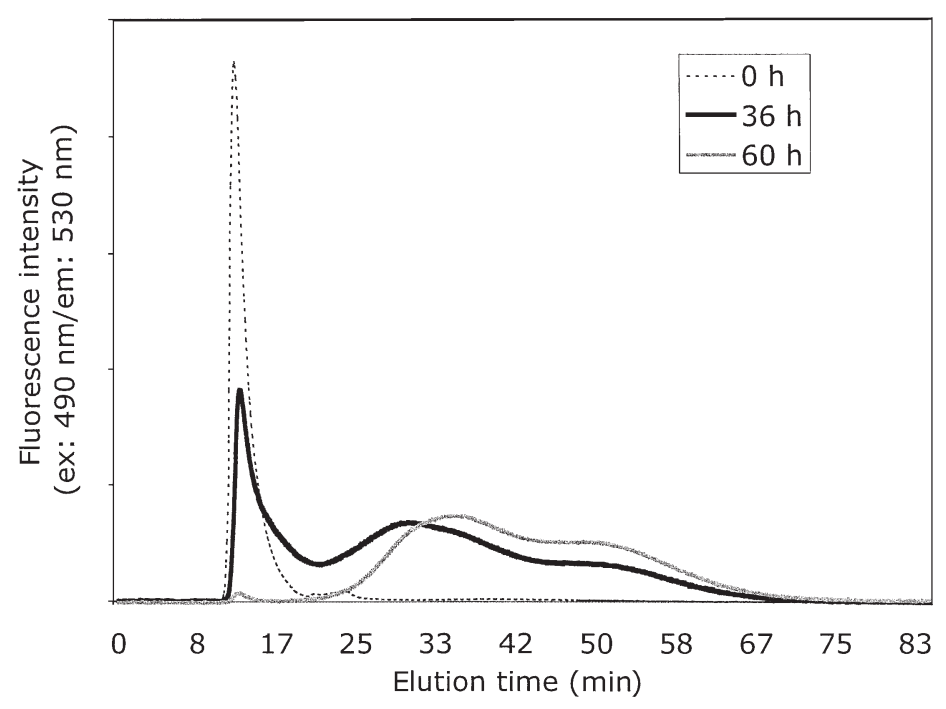

Fig. 1. Chromatograms showing the elution profiles of chondroitin sulfate (samples incubated at $18^{\circ} \mathrm{C}$ ) after 0,36 and $60 \mathrm{~h}$ incubation. Note that increasing elution time correlates with decreasing molecular weight. ex: excitation; em: emission with natural substrates of unknown concentration for enzyme active sites.

\section{RESULTS}

We used 4 structurally distinct high molecular weight polysaccharides to measure extracellular enzymatic hydrolysis rates in Arctic sediments as a function of temperature. Despite the structural differences among these polysaccharides and the probable differences among the extracellular enzymes that hydrolyze them (see first subsection of 'Discussion'), all 4 enzyme activities exhibited low temperature optima in the range of 15 to $18^{\circ} \mathrm{C}$ (Fig. 2). Chondroitin sulfate hydrolysis exhibited an almost linear increase in hydrolysis rate with increasing temperature up to an optimum temperature between 15 and $18^{\circ} \mathrm{C}$ (Fig. 2a). Above the optimum temperature, hydrolysis rates declined sharply, reaching a uniformly low level above $25^{\circ} \mathrm{C}$. Fucoidan hydrolysis likewise showed a well-defined temperature profile, with hydrolysis rates increasing steeply between the minimum temperature and the optimum temperature at $15^{\circ} \mathrm{C}$ (Fig. 2b). Above the optimum temperature, hydrolysis rates decreased rapidly, again reaching a relatively uniform low above a temperature of $25^{\circ} \mathrm{C}$. The activities of the enzymes hydrolyzing chondroitin sulfate as well as fucoidan could therefore be more closely classified as psychrophilic than psychrotolerant, since the temperature optima are close to $15^{\circ} \mathrm{C}$ and activity declines rapidly above this temperature. In accordance with a psychrotolerant classification, however, activities were still detectable above $20^{\circ} \mathrm{C}$.

The optimum temperature for hydrolysis of xylan and pullulan at Stn $\mathrm{AB}$ were in the range of 15 to $18^{\circ} \mathrm{C}$, but the hydrolysis profiles differed from those of chondroitin sulfate and fucoidan. For xylan, hydrolytic activity did not decline steeply at temperatures above the optimum, and activity at $34^{\circ} \mathrm{C}$ was still ca. $40 \%$ of the optimum (Fig. 2c). The increase in pullulanase activity from low temperatures up to the optimum temperature of $15^{\circ} \mathrm{C}$ showed considerably more scatter, and activities above $20^{\circ} \mathrm{C}$ ranged from 16 to $35 \%$ of activity at the optimum temperature (Fig. 2d). Relatively high activity at temperatures above $20^{\circ} \mathrm{C}$ is consistent with psychrotolerance, although high activity below $0^{\circ} \mathrm{C}$ is considered a psychrophilic characteristic.

The temperature profile of pullulan hydrolysis at Stn J also suggests psychrotolerant characteristics. At this station, hydrolysis was measured in parallel with sulfate reduction rates (Fig. 3). The optimum temperature of pullulan hydrolysis was $15^{\circ} \mathrm{C}$, essentially the same as at Stn AB. Overall, the temperature-hydrolysis relationship at Stn J showed less scatter than at Stn AB, with a steep increase in hydrolysis rate from $-3^{\circ} \mathrm{C}$ up to 

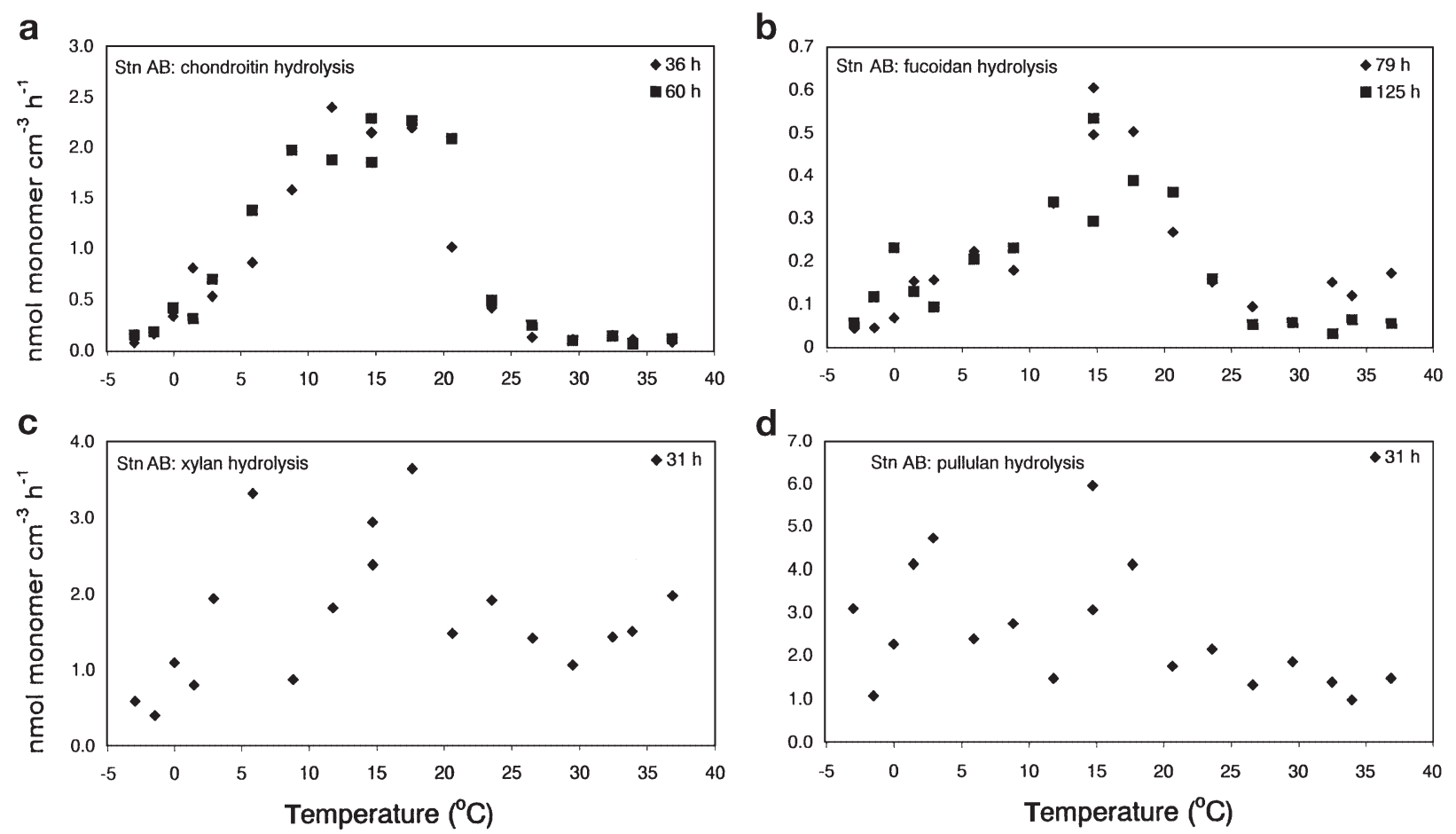

Fig. 2. Hydrolysis rates of (a) chondroitin sulfate, (b) fucoidan, (c) xylan and (d) pullulan in Stn AB sediments incubated in the temperature gradient block. Note different scales of ordinates

the optimum temperature, and a significant decrease between the optimum temperature and $30^{\circ} \mathrm{C}$. Above $30^{\circ} \mathrm{C}$, hydrolysis rates increased somewhat. For sulfate reduction at Stn $\mathrm{J}$, rates increased sharply from $-3^{\circ} \mathrm{C}$ to an optimum temperature of $21^{\circ} \mathrm{C}$, higher than the optimum temperature for enzyme activity. Above this temperature, the sulfate reduction rate decreased steeply.

For all 4 polysaccharides, potential hydrolysis rates in Stn $A B$ sediments increased by a mean factor of 6 to 7 between activity at the lowest temperatures measured and activity at the optimum temperature. Activity at $0^{\circ} \mathrm{C}$ was typically 14 to $38 \%$ of the activity reached at the optimum temperature. The potential rates at the optimum temperature differed considerably among the 4 substrates, however. Pullulan hydrolysis was most rapid, reaching a maximum rate of $6 \mathrm{nmol}$ monomer $\mathrm{cm}^{-3} \mathrm{~h}^{-1}$ at an optimum temperature of $15^{\circ} \mathrm{C}$. The optimum temperature for fucoidan hydrolysis was likewise $15^{\circ} \mathrm{C}$, but the rate at this temperature was lower by a factor of 10 , at $0.6 \mathrm{nmol} \mathrm{monomer} \mathrm{cm}^{-3} \mathrm{~h}^{-1}$. Rates of chondroitin sulfate and xylan hydrolysis were $2.4 \mathrm{nmol}$ monomer $\mathrm{cm}^{-3} \mathrm{~h}^{-1}$ and $3.6 \mathrm{nmol}$ monomer $\mathrm{cm}^{-3} \mathrm{~h}^{-1}$, respectively, at temperature optima of 15 and $18^{\circ} \mathrm{C}$. At Stn J, although the optimum temperature of pullulan hydrolysis was similar to that at $\mathrm{Stn} A B$, the hydrolysis rate at the optimum temperature, $2.4 \mathrm{nmol}$ monomer $\mathrm{cm}^{-3} \mathrm{~h}^{-1}$, was lower than at Stn $\mathrm{AB}$. Similar to Stn $\mathrm{AB}$, activity at $0^{\circ} \mathrm{C}$ was $36 \%$ of activity at the optimum temperature.
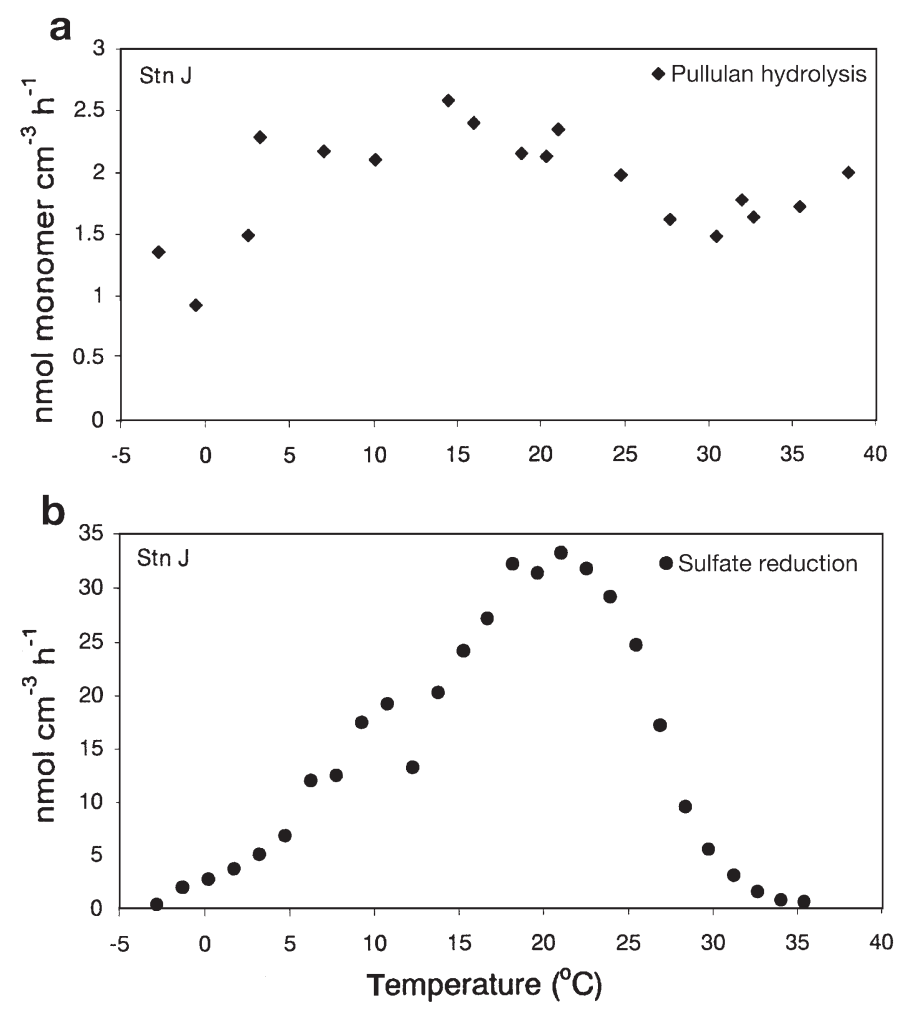

Fig. 3. (a) Hydrolysis rates of pullulan and (b) sulfate reduction rates in Stn $\mathrm{J}$ sediments incubated in the temperature gradient block. Note different scales of ordinates 


\section{DISCUSSION}

\section{Temperature characteristics of extracellular enzymes}

A focused investigation of the temperature responses of a related class of extracellular enzymes in environmental samples has not previously been carried out, primarily due to the inherent limitations of the methods most commonly used for measuring enzyme activities in such systems. Temperature responses of enzyme activities in environmental samples have most frequently been investigated using small substrate analogs, in which a fluorophore (such as methylumbelliferone) is covalently linked to a monomer such as a monosaccharide or amino acid (e.g. Helmke \& Weyland 1991, Vetter \& Deming 1994, Huston et al. 2000). Such small substrate analogs cannot adequately represent the 3-dimensional structure of a high molecular weight substrate in solution, and kinetic parameters determined using such substrate proxies can differ significantly from those of the actual polymer (Feller et al. 1996). Furthermore, these substrate proxies are probably hydrolyzed principally by exo-acting enzymes, which cleave only the terminal linkages of a polymer chains. True polymers, however, are cleaved by microorganisms using endo-acting extracellular enzymes, which can cleave polymers mid-chain, as well as by exo-acting extracellular enzymes (Henrissat \& Davies 1997).

All 4 enzyme activities measured in this study demonstrated low temperature optima of 15 to $18^{\circ} \mathrm{C}$. The similarly low temperature optima are particularly intriguing because these structurally distinct polysaccharides are very probably hydrolyzed by different extracellular enzymes, yet all 4 enzymes, by definition, would be classified as polysaccharide hydrolases. These temperature optima are in fact considerably lower than most other reported temperature optima of extracellular enzyme activities in environmental samples. Crude extracts of enzymes from Antarctic sediments showed temperature optima of 30 to $45^{\circ} \mathrm{C}$ for chitinase, agarase, protease, sulfatase, and alkaline phosphatase activities (Reichardt 1987). Chitobiase and leucine aminopeptidase activities measured at 5 different temperatures in a variety of Arctic samples also showed much higher temperature optima. In sea ice, the temperature optima of chitobiase hydrolysis and 1 of 2 leucine aminopeptidase samples were maximal at the data points at 15 and $25^{\circ} \mathrm{C}$, while the activity of the other leucine aminopeptidase sea-ice sample was maximal at $35^{\circ} \mathrm{C}$, the highest incubation temperature measured (Huston et al. 2000). In slurried sediments, chitobiase activity was maximal at the highest measured temperature (ca. $27^{\circ} \mathrm{C}$ ), and leucine aminopeptidase activity showed significant scatter and no distinguishable trend (Huston et al. 2000). The only previous report of a low temperature optimum in polar sediments was from another fjord at Svalbard, where the optimum temperature of pullulan hydrolysis was found to be $15^{\circ} \mathrm{C}$ at Hornsund, comparable to the optima measured here; at Storfjorden, however, the optimum temperature was $34^{\circ} \mathrm{C}$ (Arnosti et al. 1998).

The low temperature optima measured in these sediments are also notable because environmental temperature can affect the production as well as the activities of extracellular enzymes. The production of an extracellular enzyme by a microbial cell involves a cascade of biochemical pathways that exhibit specific temperature sensitivities. The temperature-activity relationships (as shown in Fig. 2) therefore potentially reflect distinct processes that may exhibit dissimilar temperature responses. Such dissimilar responses have already been observed in the case of the Antarctic bacterium Alteromonas haloplanctis A23. Although the generation time for a pure culture of A. haloplanctis A23 decreased from 4 to $1 \mathrm{~h}$ when cultures were grown at $18^{\circ} \mathrm{C}$ instead of $4^{\circ} \mathrm{C}$, maximum $\alpha$-amylase activity in the culture supernatant simultaneously declined by a factor of ca. 8 at $18^{\circ} \mathrm{C}$ (Feller et al. 1994a). The enzymes secreted at both temperatures had a temperature optimum of $30^{\circ} \mathrm{C}$ and exhibited the same denaturation rate (Feller et al. 1994b), suggesting that the lower activity seen in the culture grown at $18^{\circ} \mathrm{C}$ was due to a lower concentration of active enzyme (Feller et al. 1994a).

Differences in the temperature optimum of enzyme production and the temperature optimum of enzyme activity may in fact underlie the different temperature-activity profiles shown by chondroitin sulfate and fucoidan on the one hand and pullulan and xylan on the other. Both chondroitin sulfate and fucoidan show a sharp maximum with a very steep decrease at temperatures above the $T_{\text {opt }}$ (Fig. 2a,b), while pullulan and xylan show similarly low optimum temperatures, but less sharply defined profiles (Figs. 2c,d \& 3a). In order to yield sharply defined optimum temperatures, the processes of enzyme production are likely to have temperature responses similar to that of enzyme activity for chondroitin sulfate as well as for fucoidan. The less sharply defined profiles for pullulan and xylan may result from greater differences between the temperature optimum of enzyme production on the one hand and the temperature optimum of enzyme activity on the other. The lack of a sharply defined optimum temperature of pullulanase or xylanase activity may then be due to superposition of a series of dissimilar temperature-activity relationships for processes of enzyme production, excretion, and activity.

A range of other factors could equally well account for the lack of a sharply defined optimum temperature 
for pullulan and xylan hydrolysis in these sediments. The enzymes may exhibit biphasic activities, with several distinct optima. These integrative measurements may also reflect activities of structurally distinct enzymes hydrolyzing the same substrate, but with different temperature sensitivities or activities (e.g. Nguyen et al. 2001, Chhabra et al. 2002). Furthermore, any potential contribution of 'relict' enzymes (enzymes previously produced and excreted that retain activity in these sediments) to the measurements made here is entirely unknown. Distinguishing between these possibilities would require isolation and characterization of the enzymes themselves as well as the organisms responsible for their production. Despite these potential sources of variation, the relative activity for all 4 enzymes at Stn AB increased by a factor of approximately 7 between the lowest activity measured $<0^{\circ} \mathrm{C}$ and activity at the optimum temperature, suggesting similar magnitudes of response among these 4 diverse extracellular enzymes.

The temperature optima of enzyme activities measured in this study are still much higher than the in situ temperatures of close to $0^{\circ} \mathrm{C}$. This difference between in situ and optimum temperatures has also been reported for pure cultures of bacteria isolated from polar environments. For these organisms, the optimum temperature of extracellular enzyme activities has furthermore been found to greatly exceed the maximal growth temperature of the pure cultures (e.g. Helmke \& Weyland 1991, Feller et al. 1994a, Huston et al. 2000, Bendt et al. 2001).

Although this focus on temperature optima may leave the impression that these extracellular enzymes are not well adapted to in situ conditions, the key factor is the relative activity actually achieved at in situ temperatures. The activities of the 4 enzymes investigated here are all relatively high at temperatures $\leq 0^{\circ} \mathrm{C}$. Fucoidan and chondroitin sulfate reach 13 and $18 \%$, respectively, of their optimum activities at $0^{\circ} \mathrm{C}$, while pullulan and xylan hydrolysis rates at $0^{\circ} \mathrm{C}$ are on average 36 to $38 \%$ of their rates at the optimum temperatures. These relative activities are comparable to that of the cold-adapted $\alpha$-amylase of Alteromonas haloplanctis, which attained $20 \%$ of its optimum activity at $4^{\circ} \mathrm{C}$. In comparison, a mesophilic $\alpha$-amylase attained only $4 \%$ of its optimal activity at $4^{\circ} \mathrm{C}$ (Feller et al. 1994b).

The structural basis of cold adaptation of enzymes has been established through detailed molecular and biochemical investigations of a few selected enzymes (see Gerday et al. [1997] for a review). The $\alpha$-amylase of Alteromonas haloplanctis, for example, has a more 'flexible' structure than its mesophilic counterpart, achieved by a reduction in salt bridges and aromatic interactions. The enzyme also has fewer hydrophobic regions than its mesophilic counterpart (Feller et al. 1994b). Although the structures of the extracellular enzymes hydrolyzing chondroitin sulfate, fucoidan, pullulan and xylan in permanently cold environments are currently unknown, they may include similar structural adaptations to low temperatures.

\section{Implications for carbon cycling by heterotrophic microbial communities}

Extracellular enzymatic hydrolysis is the initial step in the remineralization of organic macromolecules, which must be hydrolyzed to sizes sufficiently small to be transported into microbial cells for further transformation. Sulfate reduction, the terminal step of organic carbon remineralization in anoxic marine sediments, is carried out by bacteria that oxidize low molecular weight substrates to $\mathrm{CO}_{2}$ while reducing sulfate to sulfide. The carbon conversion pathway includes an unknown number of steps and organisms in the intermediate transformations between hydrolysis and sulfate reduction. All these steps may operate at different rates and with different temperature sensitivities. Through addition of substrates for the sulfate-reducing community, temperature effects resulting from organisms and processes occurring in intermediate stages could be eliminated. The temperature responses of the initial and terminal steps in the carbon remineralization pathway could, therefore, be investigated in parallel (using the same initial slurry source incubated in the same temperature block) at Stn J.

The optimum temperature of sulfate reduction measured at Stn $\mathrm{J}$ was $21^{\circ} \mathrm{C}$, somewhat higher than the 15 to $18^{\circ} \mathrm{C}$ optima for extracellular enzymatic hydrolysis at $\mathrm{Stn} \mathrm{AB}$ and the $15^{\circ} \mathrm{C}$ optimum for pullulan hydrolysis from Stn J. However, this temperature optimum for sulfate reduction is considerably lower than the 26 to $30^{\circ} \mathrm{C}$ optima measured in a previous investigation of the temperature dependence of sulfate reduction in Svalbard sediments (Sagemann et al. 1998). Sulfate reduction rates in Stn $\mathrm{J}$ sediments were also considerably higher at in situ as well as at optimum temperatures (2.8 and $33.1 \mathrm{nmol}$ sulfate $\mathrm{cm}^{-3}$ sediment $\mathrm{h}^{-1}$, respectively; Fig $3 \mathrm{~b}$ ) than those previously measured in temperature gradient experiments (with and without added substrates) using Svalbard sediments (up to $0.83 \mathrm{nmol}$ sulfate $\mathrm{cm}^{-3}$ sediment $\mathrm{h}^{-1}$; Sagemann et al. 1998). Some of these differences may be due to sedimentary organic matter, as the sediments in previous investigations were from different stations and deeper depths (8-13 and 9-14 $\mathrm{cm}$ compared to 3-7 cm for Stn J). The Stn J samples were also incubated for a longer period $(2.1 \mathrm{~d}$, compared to $4-5 \mathrm{~h}$ for the previous investigation). 
The temperature response of sulfate reduction at Stn $\mathrm{J}$ is consistent with available information about members of the psychrophilic sulfate-reducing microbial community in Svalbard sediments. Isolation and detailed investigation of 5 psychrophilic sulfate-reducing bacteria from 2 fjords of Svalbard demonstrated that these organisms have temperature optima for growth ranging from 7 to $18^{\circ} \mathrm{C}$, while their temperature optima for sulfate reduction are 2 to $9^{\circ} \mathrm{C}$ above their growth optima (Knoblauch \& Jørgensen 1999), consistent with the $21^{\circ} \mathrm{C}$ optimum temperature for sulfate reduction measured at Stn J. Furthermore, molecular biological investigations have demonstrated that these psychrophilic isolates constitute a substantial fraction of the sulfate reducing community and comprise 1.4 to $20.9 \%$ of total eubacterial rRNA detectable in Svalbard sediments (Sahm et al. 1999).

The temperature responses of both the initial and the terminal steps in the carbon remineralization pathway indicate adaptations to permanently cold temperatures. The extent to which these 2 steps are correlated can be approximated by comparing carbon turnover via potential hydrolysis with sulfate reduction rates at Stn J. To estimate how much organic carbon pullulanase enzymes could potentially feed into the carbon remineralization pathway, the quantity of monosaccharides which could in theory be produced by these enzymes at each incubation temperature was calculated on a carbon-equivalent basis (1 nmol glucose = 6 nmol C; Fig. 4: $\diamond$ ). Carbon consumption via sulfate reduction was calculated assuming that $2 \mathrm{~mol}$ of carbon were oxidized for each mole of sulfate reduced (Fig. 4: ๑). Fig. 4 shows that in the lower temperature range (up to ca. $5^{\circ} \mathrm{C}$ ), pullulan hydrolysis could potentially supply sufficient organic carbon to fuel all of the sulfate reduction measured in the TGB. At the optimum temperature for sulfate reduction, pullulan hydrolysis could still potentially supply $21 \%$ of carbon

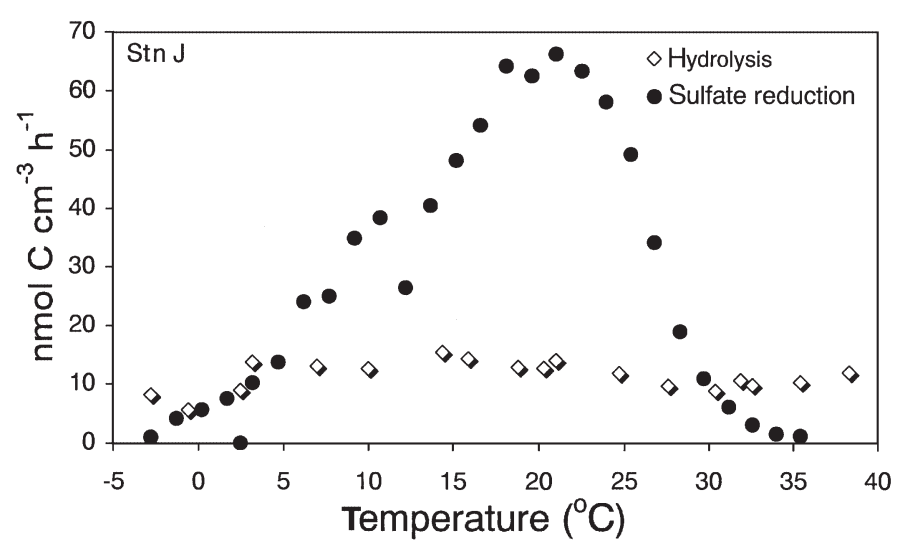

Fig. 4. Comparison of carbon potentially hydrolyzed via extracellular enzymes with carbon remineralization via sulfate reduction at Stn $\mathrm{J}$ consumed via sulfate reduction (Fig. 4). This comparison clearly shows that extracellular enzymatic hydrolysis is not a priori the slow step in carbon remineralization in these sediments.

A more comprehensive picture of potential carbon supply to sulfate reducers should include the activities of a much broader range of extracellular enzymes, including polysaccharide hydrolases of different structural specificities, as well as proteases and lipases. Such a calculation at Stn J would probably show a vast excess of potential carbon supply to sulfate reducers. Where, then, are the slow steps in the carbon remineralization pathway? Potential hydrolysis rates themselves provide no information about the concentration of suitable substrate actually present. Only substrates whose chemical structure corresponds to the active site of a specific enzyme can be hydrolyzed by that enzyme, so the pool of substrates available to be hydrolyzed by a given enzyme probably constitutes only a small fraction of the total carbohydrate pool which, in turn, constitutes only a portion of sedimentary organic carbon.

The contribution of carbohydrates, a major class of biomolecules, to sedimentary organic carbon has been investigated in numerous studies (e.g. Cowie \& Hedges 1984, Wakeham et al. 1997, Arnosti \& Holmer 1999), but these and other investigations of carbohydrate concentrations provide no information on aspects of structure which are critical for enzymatic activity. Since standard techniques of carbohydrate analysis require acid hydrolysis, no information on carbohydrate secondary or tertiary structure can be obtained. Furthermore, even measurements of monomer composition (\% glucose, galactose, fucose, etc.) cannot indicate which monomers are linked together in any given structure. Without this information, currently unobtainable using standard analytical techniques, we can only speculate about the concentration and specific nature of polysaccharides in sedimentary organic carbon. The fact that all the polysaccharides used in the present study are marine-derived and/or the enzymes hydrolyzing these polysaccharides have been demonstrated to occur in marine prokaryotes suggests that they are relevant as substrates, but quantification of specific polysaccharides as components of sedimentary organic carbon awaits the development of new analytical approaches.

A further consideration is the range in observed activities of different extracellular enzymes. Fucoidan, chondroitin sulfate, and xylan hydrolysis at the in situ temperature at Stn $\mathrm{AB}$ were only 3, 15, and $49 \%$, respectively, of the rate of pullulan hydrolysis, so the activities of these extracellular enzymes (assuming their relative activities are similar at Stns $\mathrm{AB}$ and J) could potentially provide a proportionately smaller 
fraction of the total organic carbon ultimately remineralized in these sediments. If carbohydrates in Svalbard sediments were more similar to fucoidan than to pullulan, therefore, rates of hydrolysis of naturally occurring polysaccharides would be correspondingly decreased. Other, more complex substrates, might be hydrolyzed even more slowly.

The differences in potential hydrolysis rates of chondroitin sulfate, fucoidan, pullulan and xylan may be caused by biochemical and biophysical properties of the enzymes themselves (leading to different enzyme turnover numbers), as well as by differences in the absolute quantities of specific extracellular enzymes present in the sediments. Measurement of a potential hydrolysis rate in an environmental sample cannot be used to distinguish between a high rate due to highly active enzymes or a high rate that is due to a large quantity of enzymes. Differences in quantities of enzymes active in sediments may depend in turn on several factors. Only a subfraction-of unknown size and composition - of the sedimentary microbial community possesses the capability of producing a specific enzyme. Expression of specific extracellular enzymes by these organisms may require the presence of an inducer or be regulated by quorum-sensing mechanisms, so the ability to produce a given enzyme does not necessarily correlate with actual enzyme production. Even among homogenous populations in culture, frequency of gene expression for a given extracellular enzyme can vary widely (e.g. Baty et al. 2000). A further 'unknown' is the amount of time during which a particular extracellular enzyme, once excreted, retains activity in the environment. The persistence of a portion of organic carbon in sediments (as exemplified by the 'G model' of carbon degradation: see Westrich \& Berner 1984) demonstrates that microbial access to carbon substrates can be limited by factors that currently are not well understood.

\section{CONCLUSIONS}

In the permanently cold sediments of Svalbard, the activities of extracellular enzymes hydrolyzing 4 structurally dissimilar polysaccharides exhibited remarkably low temperature optima. All 4 activities also achieved a high percentage of optimum activity at the in situ temperature near $0^{\circ} \mathrm{C}$. These features are typical of cold-adapted extracellular enzymes (e.g. Gerday et al. 1997). The fact that the diverse range of polysaccharide-hydrolyzing enzyme activities investigated here display similar temperature characteristics suggests that such characteristics might be a general feature of at least some classes of microbial extracellular enzymes expressed in permanently cold environments.
Sulfate reduction rates were investigated in parallel with extracellular enzymatic hydrolysis at 1 station. The TGB profile of sulfate reduction showed a relatively low temperature optimum, consistent with a recent report on sulfate reduction by pure cultures of psychrophilic bacteria isolated from Svalbard sediments (Knoblauch \& Jørgensen 1999). A quantitative comparison of potential carbon flow from enzymatic hydrolysis through terminal remineralization demonstrated that the activity of just one type of extracellular enzyme could theoretically supply 21 to $100 \%$ of all the carbon consumed via sulfate reduction. Extracellular enzymatic hydrolysis is not intrinsically slow, but the natural supply of substrates suitable for rapid hydrolysis by extracellular enzymes is probably limited.

Acknowledgements. We thank Stig Henningsen (captain) and John Mortensen (1st mate) for the productive and enjoyable sampling trips aboard RV 'Farm'; Ole Larsen, Niko Finke, Volker Brüchert, and Marc Mussman for a cheerful and stimulating work environment; and Natalène Guerard (UNC) and Kirsten Neumann (MPI) for invaluable assistance with sample analysis. We also thank 3 anonymous reviewers for their thoughtful comments. This project was supported with funding from NSF (OCE, OPP, and INT) to C.A., as well as by the Max Planck Society. C.A. was a Fellow at the Hanse Wissenschaftskolleg, Delmenhorst, while writing the manuscript.

\section{LITERATURE CITED}

Adams MWW (1993) Enzymes and proteins from organisms that grow near and above $100^{\circ} \mathrm{C}$. Annu Rev Microbiol 47: $627-658$

Arnosti C (1995) Measurement of depth- and site-related differences in polysaccharide hydrolysis rates in marine sediments. Geochim Cosmochim Acta 59:4247-4257

Arnosti C (2000) Substrate specificity in polysaccharide hydrolysis: contrasts between bottom water and sediments. Limnol Oceanogr 45:1112-1119

Arnosti C, Holmer M (1999) Carbohydrate dynamics and contributions to the carbon budget of an organic-rich coastal sediment. Geochim Cosmochim Acta 63:393-403

Arnosti C, Jørgensen BB, Sagemann J, Thamdrup B (1998) Temperature dependence of microbial degradation of organic matter in marine sediments: polysaccharide hydrolysis, oxygen consumption, and sulfate reduction. Mar Ecol Prog Ser 159:59-70

Baty AM III, Eastburn CC, Diwu Z, Techkarnjanaruk S, Goodman AE, Geesey GG (2000) Differentiation of chitinase-active and non-chitinase-active subpopulations of a marine bacterium during chitin degradation. Appl Environ Microbiol 66:3566-3573

Bendt A, Hüller H, Kammel U, Helmke E, Schweder T (2001) Cloning, expression, and characterization of a chitinase gene from the Antarctic psychrotolerant bacterium Vibrio sp. strain Fi:7. Extremophiles 5:119-126

Benner R, Pakulski JD, McCarthy M, Hedges JI, Hatcher PG (1992) Bulk chemical characteristics of dissolved organic matter in the ocean. Science 255:1561-1564

Chhabra SR, Shockley KR, Ward DE, Kelly RM (2002) Regulation of endo-acting glycosyl hydrolases in the hyperther- 
mophilic bacterium Thermotoga maritima grown on glucan- and mannan-based polysaccharides. Appl Environ Microbiol 68:545-554

Cowie GL, Hedges JI (1984) Carbohydrate sources in a coastal marine environment. Geochim Cosmochim Acta 48:2075-2087

Feller G, Narinx E, Arpigny JL, Zekhnini Z, Swings J, Gerday C (1994a) Temperature dependence of growth, enzyme secretion and activity of psychrophilic Antarctic bacteria. Appl Microbiol Biotechnol 41:477-479

Feller G, Payan F, Theys F, Qian M, Haser R, Gerday C (1994b) Stability and structural analysis of $\alpha$-amylase from the Antarctic psychrophile Alteromonas haloplanctis A23. Eur J Biochem 222:441-447

Feller G, Narinx E, Arpigny JL, Aittaleb M, Baise E, Genicot S, Gerday C (1996) Enzymes from psychrophilic organisms. FEMS Microbiol Rev 18:189-202

Fossing H, Jørgensen BB (1989) Measurement of bacterial sulfate reduction in sediments: evaluation of a single-step chromium reduction method. Biogeochemistry 8:205-222

Gerday C, Aittaleb M, Arpigny JL, Baise E, Chessa JP, Garsoux G, Petrescu I, Feller G (1997) Psychrophilic enzymes: a thermodynamic challenge. Biochim Biophys Acta 1342:119-131

Glud RN, Holby O, Hoffmann F, Canfield DE (1998) Benthic mineralization and exchange in Arctic sediments (Svalbard). Mar Ecol Prog Ser 173:237-251

Helmke E, Weyland H (1991) Effect of temperature on extracellular enzymes occurring in permanently cold marine environments. Kieler Meeresforsch (Sonderh) 8:198-204

Henrissat B, Davies G (1997) Structural and sequence-based classification of glycoside hydrolases. Curr Opin Struct Biol 7:637-644

Huston AL, Krieger-Brockett BB, Deming JW (2000) Remarkably low temperature optima for extracellular enzyme activity from Arctic bacteria and sea ice. Environ Microbiol 2:383-388

Jørgensen BB (1978) A comparison of methods for the quantification of bacterial sulfate reduction in coastal marine sediments. Geomicrobiol J 1:11-27

Editorial responsibility: Otto Kinne (Editor), Oldendorf/Luhe, Germany
Knoblauch C, Jørgensen BB (1999) Effect of temperature on sulphate reduction, growth rate and growth yield in five psychrophilic sulphate-reducing bacteria from Arctic sediments. Environ Microbiol 1:457-467

Knoblauch C, Jørgensen BB, Harder J (1999) Community size and metabolic rates of psychrophilic sulfate-reducing bacteria in Arctic marine sediments. Appl Environ Microbiol 65:4230-4233

Nguyen TN, Borges KM, Romano AH, Noll KM (2001) Differential gene expression in Thermotoga neapolitana in response to growth substrate. FEMS Microbiol Lett 195: 79-83

Pace NR (1997) A molecular view of microbial diversity and the biosphere. Science 276:734-740

Reichardt W (1987) Differential temperature effects on the efficiency of carbon pathways in Antarctic marine benthos. Mar Ecol Prog Ser 40:127-135

Sagemann J, Jørgensen BB, Greef O (1998) Temperature dependence and rates of sulfate reduction in cold sediments of Svalbard, Arctic Ocean. Geomicrobiol J 15:85-100

Sahm K, Knoblauch C, Amann R (1999) Phylogenetic affiliation and quantification of psychrophilic sulfate-reducing isolates in marine Arctic sediments. Appl Environ Microbiol 65:3976-3981

Thamdrup B, Fleischer S (1998) Temperature dependence of oxygen respiration, nitrogen mineralization, and nitrification in Arctic sediments. Aquat Microb Ecol 2:191-199

Vetter YA, Deming JW (1994) Extracellular enzyme activity in the Arctic Northeast Water polynya. Mar Ecol Prog Ser 114:23-34

Wakeham SG, Lee C, Hedges JI, Hernes PJ, Peterson ML (1997) Molecular indicators of diagenetic status in marine organic matter. Geochim Cosmochim Acta 61: 5363-5369

Weiss MS, Abele U, Weckesser J, Welte W, Schiltz E, Schulz GE (1991) Molecular architecture and electrostatic properties of a bacterial porin. Science 254:1627-1630

Westrich JT, Berner RA (1984) The role of sedimentary organic matter in bacterial sulfate reduction: the $\mathrm{G}$ model tested. Limnol Oceanogr 29:236-249

Submitted: June 5, 2002; Accepted: October 30, 2002

Proofs received from author(s): February 13, 2003 